19. Часнікова О. В. Компетентнісний підхід в освіті як основа iii реформування. URL: https://www. narodnaosvita.kiev.ua/?page_id=2607 (дата звернення: 25.06.2020).

20. Шапран Ю. Педагогічне моделювання у процесі формування професійної компетентності майбутнього вчителя біології. Рідна школа. 2012. № 12. C. $39-43$.
21. Ягупов В. В., Свистун В. І. Компетентнісний підхід до підготовки фахівців у системі вищої освіти. URL: http://ekmair.ukma.edu.ua/bitstream/handle/123456 789/6871/Yagupov Svy\%60stun KOMPETENT NISNY\%60J PIDXID.pdf? sequence $=\overline{3}$ (дата звернення: $13.07 .20 \overline{20})$.

Дата надходження до редакиї: 30.07.2020 p.
УДК 37.013:001.895

DOI: 10.37026/2520-6427-2020-103-3-29-32

\section{Олександр ПАСТОВЕНСЬКИЙ,}

доктор педагогічних наук,

професор кафедри суспільно-гуманітарних дисииплін КЗ «Житомирський ОІППО»

Житомирської обласної ради,

заслужений прачівник освіти Украӥни

\title{
СИСТЕМНИЙ ПІДХІД У РЕАЛІЗАЦІЇ ІДЕЙ ПЕДАГОГІКИ ПАРТНЕРСТВА
}

У статті на основі системного підходу проаналізовано особливості реалізаиії ідей педагогіки партнерства в системі загальної середньої освіти. Зроблено висновок, шзо для ефективного впровадження ідей педагогіки партнерства необхідно забезпечити: різноманітність суб 'єктів партнерських взаємодій; розиирення сфери, де реалізуються зазначені взаємодї; урізноманітнення партнерських взаємодій в управлінні прочесами в закладах освіти; урахування рівня розвитку освітніх систем.

Ключові слова: системний підхід, педагогіка партнерства, освітня система, взаємодія, різноманітність, процес, управління, рівень розвитку.

В статье на основе системного подхода проанализированы особенности реализащии идей педагогики партнерства в системе общего среднего образования. Сделан вывод, что для эффективного внедрения идей педагогики партнерства необходимо обеспечить: разнообразие субъектов партнерских взаимодействий; расширение сферы, где реализуются указанные взаимодействия; разнообразие партнерских взаимодействий в управлении прочессами в учебных заведениях; учет уровня развития образовательных систем.

Ключевые слова: системный подход, педагогика партнерства, образовательная система, взаимодействие, разнообразие, прочесс, управление, уровень развития.

Implementation of the ideas of partnership pedagogy is one of the most important areas of modernization of the educational branch.

At the same time, the somewhat narrow interpretation of the pedagogy of partnership only as a cooperation of students, teachers and parents is one of the reasons for low efficiency of its implementation in practice.

The article proposes to expand the range of partners in interactions aimed at improving the educational process on the basis of a systems approach. Such partners may be the founder, the authorized body, the directorate of the educational institution, teachers, other employees of the institution, students, parents, self-governing bodies of the institution, the board of trustees, institutions of resource provision and support of educational and managerial activities, public associations educational process, etc.

It is emphasized that in the process of implementing the ideas of partnership pedagogy, one should take into consideration the fact that educational systems can have different levels of development - from a rigid system to a system with delegated management powers, a «soft» system, a network system and a synergy system.

The article also proposes to implement the ideas of partnership pedagogy in all major processes taking place in the educational system. The educational process, the development of the educational environment, the management process are among them.

In addition, it is emphasized that the pedagogy of partnership is important to be considered as a partnership of stakeholders at all stages of process management in the institution - from analysis and planning to organization, control and correction.

It is concluded that in order to successfully implement the ideas of partnership pedagogy in the system of general secondary education it is necessary to ensure: diversity of subjects of partnership interactions; expansion of the sphere where partnership ties are implemented; diversification of partnership relations in management processes in educational institutions; taking into consideration the levels of development of educational systems.

Key words: systems approach, partnership pedagogy, educational system, interaction, diversity, process, management, level of development.

Постановка проблеми. У статті 22 Закону України «Про повну загальну середню освіту» сформульована вимога до педагогічних працівників закладів загальної середньої освіти щодо дотримання принципів педагогіки партнерства у відносинах 3 учнями та їхніми батьками [6]. 
У Концепції реалізації державної політики у сфері реформування загальної середньої освіти «Нова українська школа» на період до 2029 року зазначено, що педагогіка партнерства, що грунтується на співпраці учнів, вчителів і батьків, $є$ одним із найважливіших напрямків модернізації освітньої галузі [7].

Основними принципами педагогіки партнерства визначено повагу до особистості, довіру у відносинах, діалог, взаємодію та взаємоповагу, розподілене лідерство (проактивність, право вибору та відповідальність за нього, горизонтальність зв'язків), соціальне партнерство (рівність усіх сторін, добровільність у прийнятті зобов'язань, обов'язковість у виконанні домовленостей) [2].

Однак наразі педагогіка партнерства недостатньо активно впроваджується в системі загальної середньої освіти України. Однією з причин цього є проблеми в обгрунтуванні теоретичних засад зазначеного феномену.

Аналіз наукових досліджень і публікацій. Біля витоків гуманістичної педагогіки в Україні стояв В. Сухомлинський.

Розроблення ідей педагогіки співробітництва здійснювали І. Іванов (методика організації колективних творчих справ), Ш. Амонашвілі, І. Волков, С. Ільїн, В. Караковський, С. Лисенкова, В. Шаталов, М. Щетинін (основні ідеї педагогіки співробітництва).

Проблеми гуманізації освіти, демократизації взаємодії учасників освітнього процесу, розвитку педагогіки партнерства розглядали у своїх працях В. Андрущенко, Г. Балл, І. Бех, В. Бондар, Л. Вовк, О. Вознюк, С. Гончаренко, М. Гузик, О. Захаренко, М. Єфименко, В. Дяченко, І. Зязюн, О. Коханова, В. Кузь, В. Кремень, В. Моргун, Д. Пащенко, І. Підласий, О. Савченко, Г. Селевко, М. Стельмахович, Г. Татаринцева, Т. Федірчик, А. Хуторський, Н. Шигонська, М. Ярмаченко та ін.

Мета статті - проаналізувати на основі системного підходу особливості реалізації ідей педагогіки партнерства в системі загальної середньої освіти.

Виклад основного матеріалу. Дещо звужене, на наш погляд, трактування в Концепції «Нова українська школа» педагогіки партнерства як співпраці лише учнів, учителів $i$ батьків [7] є однією з причин невисокої ефективності впровадження іiї в практику.

Ми пропонуємо розглядати зазначений феномен на основі системного підходу як партнерську взаємодію всіх суб'єктів освітньої системи.

Підкреслимо, що ці суб'єкти чітко визначені в Законі України «Про повну загальну середню освіту» (2020). Так, у статті 19 зазначено, що в освітньому процесі в закладах загальної середньої освіти беруть участь педагогічні працівники, учні та їхні батьки, інші працівники цього закладу, а також із дозволу директора до проведення занять, позакласних і позашкільних заходів, оцінювання результатів навчальної діяльності можуть залучатися будь-які інші особи [6].

Крім того, у статті 36 означеного Закону зазначається, що управління закладом освіти здійснюється засновником (найчастіше це - відповідна рада) та/ або уповноваженим ним органом, дирекцією закладу, педагогічною радою, загальними зборами трудового колективу, а також, у межах, визначених законодавством і статутом закладу, органами самоврядування працівників, учнів, батьків, піклувальною радою [6]. Тобто, зазначені органи також можуть брати участь у партнерських взаємодіях у закладі освіти як учасники освітнього процесу в широкому його розумінні.

Варто підкреслити, що відповідно до статті 52 участь в освітньому процесі можуть брати також інституції, що забезпечують інформаційну та науково-методичну підтримку системи загальної середньої освіти: Національна академія педагогічних наук України та їі установи, органи із забезпечення якості освіти, центри професійного розвитку педагогічних працівників, інклюзивно-ресурсні центри, міжшкільні ресурсні центри, заклади освіти, в тому числі післядипломної, науково-методичні та методичні установи, громадські об'єднання, незалежні організації $з$ оцінювання та забезпечення якості освіти тощо [6].

Таким чином, на основі системного підходу ми значно розширюємо коло можливих партнерів у взаємодіях, що спрямовані на поліпшення освітнього процесу. Це важливо враховувати педагогічним працівникам і керівникам освітньої галузі під час організації відповідної роботи.

На нашу думку, доцільно розглянути ще одну проблему. На сучасному етапі в процесі реалізації ідей педагогіки партнерства основна увага акцентується на взаємодї та співпраці між учителям, учнями й батьками [7]. Однак при цьому не розрізняються рівні такої взаємодї, які, на нашу думку, визначаються рівнем розвитку освітніх систем.

Нами обгрунтовано, що в партнерських взаємодіях керівництва закладу освіти та громадських структур освітні системи проходять фази розвитку від жорсткої системи $\left(\mathrm{C}_{ж}\right)$ до системи 3 делегованими управлінськими повноваженнями $\left(\mathrm{C}_{2 \Pi}\right)$, «м'якої» системи $\left(\mathrm{C}_{\mathrm{M}}\right)$, системи 3 мережевою взаємодією $\left(\mathrm{C}_{\mathrm{MB}}\right)$ і синергетичної системи $\left(\mathrm{C}_{\mathrm{C}}\right): \mathrm{C}_{\text {ж }} \rightarrow \mathrm{C}_{\text {дп }} \rightarrow \mathrm{C}_{\mathrm{M}} \rightarrow \mathrm{C}_{\mathrm{MB}} \rightarrow \mathrm{C}_{\mathrm{C}}$ [4].

Зауважимо, що в жорсткій системі управління здійснюється лише керівництвом закладу освіти, у системі з делегованими управлінськими повноваженнями частина цих повноважень передається органам самоврядування працівників закладу, учнів, батьків; у «м'якій» системі основні управлінські рішення узгоджуються зазначеними вище структурами; у системі 3 мережевою взаємодією до прийняття управлінських рішень через мережеву взаємодію залучаються також інші громадські структури закладу освіти, педагоги, батьки й учні; у синергетичній системі участь в управлінні на основі визначених процедур беруть усі стейкхолдери, тобто зацікавлені особи.

Зважаючи на викладене вище, ідеї педагогіки партнерства можуть реалізуватися в різних фазах розвитку освітніх систем у такий спосіб:

- жорстка система - ідеї педагогіки партнерства практично не реалізовуються, відбувається лише спілкування учасників освітнього процесу в межах основних напрямків діяльності закладу освіти;

- система з делегованими повноваженнями - в окремих питаннях управління закладом освіти здійснюється партнерська взаємодія дирекції та органів самоврядування працівників закладу, учнів, батьків; в основних питаннях управлінської діяльності відбуваються консультації зазначених структур;

- «м'яка» система - ідеї педагогіки партнерства реалізуються на основі партнерської взаємодії керівництва закладу освіти та органів самоврядування працівників, учнів, батьків шляхом узгодження ними основних управлінських рішень;

- система з мережевою взаємодією - ідеї педагогіки партнерства реалізуються на основі партнерської взаємодії керівництва закладу освіти та органів самоврядування працівників, учнів, батьків шляхом узгодження ними основних управлінських рішень i мережевого консультування з цих питань зазначених структур з усіма учасниками освітнього процесу; 
- синергетична система - ідеї педагогіки партнерства реалізуються на основі партнерської взаємодії стейкхолдерів шляхом узгодження ними основних управлінських рішень на всіх етапах управління закладом освіти.

Отже, у процесі реалізації ідей педагогіки партнерства й опрацювання алгоритмів відповідних дій із метою забезпечення їхньої ефективності обов'язково потрібно враховувати рівень розвиту освітньої системи.

Ще однією проблемою в упровадженні ідей педагогіки партнерства, на наш погляд, $є$ те, що в більшості випадків під час планування партнерських взаємодій не зовсім чітко виокремлюються процеси, де мають відбуватися ці взаємодії. Найчастіше увага акцентується на виховному процесі й організації різноманітних виховних заходів на кшталт спільного проведення вчителями, учнями та батьками шкільних свят, фестивалів, змагань, екскурсій, походів, театральних постановок, зустрічей, профорієнтаційних годин тощо.

Ми пропонуємо розширити сферу застосування партнерських взаємодій на всі процеси, що відбуваються в освітній системі. Серед них виокремлюємо освітній процес, зокрема й виховний, процеси розвитку освітнього середовища, професійного розвитку педагогічних працівників, управлінський, фізкультурно-оздоровчий процеси, а також процеси інформаційного, науково-методичного, кадрового, фінансового забезпечення закладу освіти тощо.

Щодо освітнього процесу зазначимо, що відповідно до статті 4 Закону України «Про повну загальну середню освіту» формами здобуття повної загальної середньої освіти є: очна (денна), очна (вечірня), заочна, мережева, дистанційна, екстернатна, сімейна, дуальна та педагогічний патронаж [6]. У кожній із цих форм партнерська взаємодія учасників освітнього процесу відбувається з урахуванням їхніх конкретних особливостей, що потрібно враховувати під час вибору відповідних видів, форм і методів навчання в педагогіці партнерства (групові завдання, тематична дискусія, навчальний тренінг, адаптивне, проєктне навчання, гейміфікація, змішане, перевернуте, електронне, мобільне навчання, вебквест, семінар, практикум тощо).

Серед видів виховання більшість науковців і педагогів-практиків виокремлюють національно-патріотичне, громадянсько-правове, морально-етичне, трудове, інтелектуально-духовне, художньо-естетичне, екологічне, фізичне виховання та формування здорового способу життя. У кожному з цих видів партнерські взаємодії та відповідні їм форми й методи виховання в педагогіці партнерства будуть визначатися особливостями конкретного виду виховання й рівнем розвитку освітньої системи.

Що стосується процесу розвитку освітнього середовища, то тут можна виділити такі напрями:

- створення безпечних і комфортних умов навчання й праці, здійснення профілактичних заходів щодо збереження життя та здоров'я учнів (дотримання вимог щодо охорони праці, безпеки життєдіяльності, пожежної безпеки, створення належних умов для харчування, безпечного користування інтернетом тощо);

- створення освітнього середовища, вільного від дискримінації та насильства, протидія й попередження булінгу;

- розвиток інклюзивного, розвивального й мотивуючого до навчання освітнього простору, забезпечення сприятливих умов для учнів, залежно від їхніх потреб, здібностей, можливостей та інтересів [5].
Поліпшення освітнього середовища в кожному 3 означених напрямів, як підтверджує практичний досвід, найефективніше здійснювати на основі партнерських взаємодій усіх стейкхолдерів.

Аналогічно можна проаналізувати й інші процеси, що відбуваються в закладі освіти, які будуть успішніше розвиватися під час поєднання зусиль зацікавлених сторін.

Важливою проблемою в упровадженні ідей педагогіки партнерства $є$ те, що в процесі реалізації зазначених ідей основна увага звертається на співпрацю учасників освітнього процесу в організації та проведенні відповідних освітніх заходів. Ми пропонуємо розглядати педагогіку партнерства ширше - як партнерську взаємодію стейкхолдерів в управлінні процесами, що відбуваються в закладі освіти. Для цього розглянемо одну 3 найпоширеніших класифікацій загальних функцій управління, де виокремлено: аналіз (діагностику), планування, організацію, контроль, регулювання (корекцію) [1, с. 20].

Схарактеризуємо складові зазначених функцій, що деталізують напрями управлінської діяльності, де доцільно забезпечувати партнерські взаємодії [5]:

1) аналіз (діагностика): аналіз внутрішньої та зовнішньої інформації щодо відповідності результатів діяльності закладу освіти державним стандартам і нормам; аналіз спроможності закладу до виконання освітніх запитів; інтегральна діагностика стану та проблем закладу;

2) планування: визначення мети й цілей діяльності закладу освіти, факторів і критеріїв оцінювання результатів його діяльності; моделювання очікуваного стану системи й окреслення основних напрямів дій; визначення необхідних структур, виконавців та етапів діяльності, ресурсів для досягнення мети; розроблення плану діяльності; оприлюднення моделі та плану діяльності;

3) організація: підготовка структур та окремих осіб-виконавців до реалізації плану діяльності, визначення їхніх повноважень, налагодження комунікацій; конкретизація та деталізація цілей, етапів, форм і методів діяльності; забезпечення ресурсів та умов (правових, фінансових, матеріально-технічних, психологічних) для реалізації плану; регламентація діяльності, встановлення комунікацій $з$ партнерськими структурами; мотивація учасників діяльності; координація діяльності 3 реалізації розробленого плану;

4) контроль: планування контрольних заходів; організація контролю; збір інформації щодо стану об’єктів перевірки; аналіз результатів контролю та розроблення рекомендацій щодо корекції діяльності закладу освіти; оприлюднення результатів контролю та рекомендацій щодо корекції діяльності закладу;

5) регулювання (корекція): корекція моделі, критеріїв оцінювання результатів, напрямів діяльності та плану дій; корекція структур та/або заміна окремих виконавців, доведення до виконавців змісту змін, їхня додаткова мотивація; покращення ресурсного забезпечення й умов діяльності; координація діяльності з реалізації скоригованого плану дій.

Зрозуміло, що для успішної реалізації ідей педагогіки партнерства й підвищення ефективності освіти стейкхолдерам доцільно налагоджувати партнерські взаємодії на всіх напрямах управління процесами, що відбуваються в закладах - від аналізу й планування до організації, контролю та корекції. 
Висновки. Представлений у статті аналіз особливостей реалізації ідей педагогіки партнерства засвідчив доцільність застосування системного підходу до вирішення цієї проблеми. У межах зазначеного підходу встановлено, що для успішного впровадження ідей педагогіки партнерства необхідно забезпечити: різноманітність суб'єктів партнерських взаємодій; розширення сфери, де реалізуються партнерські взаємодії; урізноманітнення партнерських взаємодій в управлінні процесами в закладах освіти; врахування рівня розвитку освітніх систем.

Перспективи подальших досліджень. Водночас, зважаючи на виокремлені вище умови ефективної реалізації ідей педагогіки партнерства, важливим є дослідження проблеми визначення відповідних їм форм і методів педагогічної діяльності й управління освітою.

\section{СПИСОК ВИКОРИСТАНОЇ ЛІТЕРАТУРИ}

1. Мармаза О. І. Менеджмент освітньої організації. Харків : ТОВ «Щедра садиба», 2017. 126 с.

2. Нова українська школа. Концептуальні засади реформування середньої школи. 2016. URL: https:// mon.gov.ua/storage/app/media/zagalna\%20serednya/ nova-ukrainska-shkola-compressed.pdf (дата звернення: 22.09.2020).

УДК 377.02

DOI: 10.37026/2520-6427-2020-103-3-32-35
3. Пастовенський О. В. Особливості реалізації функцій управління освітою в умовах розвитку освітніх систем. Народна освіта : електронне наукове фахове видання. 2019. Вип. 3 (18). URL: https://www.narodnaosvita. kiev.ua/?page_id=5532 (дата звернення: 22.09.2020).

4. Пастовенський О. В. Синергетичний сценарій розвитку ефективних освітніх систем. Вісник Житомирського державного університету імені Івана Франка. Педагогічні науки. 2016. Вип. 2(84). С. 102-106.

5. Про затвердження Порядку проведення інституційного аудиту закладів загальної середньої освіти (зі змінами) : Наказ Міністерства освіти і науки України від 09.01.2019 p. № 17. 2019. URL: https://zakon.rada.gov.ua/ laws/show/z0250-19\#Техt (дата звернення: 20.09.2020).

6. Про повну загальну середню освіту : Закон України від 13.07.2020 р. № 764-IX. URL: https:// zakon.rada.gov.ua/laws/show/463-20\#Text (дата звернення: 21.09.2020).

7. Про схвалення Концепції реалізації державної політики у сфері реформування загальної середньої освіти «Нова українська школа» на період до 2029 року : розпорядження Кабінету Міністрів України від 14.12.2016 р. № 988-p. 2016. URL: https://zakon.rada.gov.ua/laws/show/ 988-2016-\%D1\%80\#Техt (дата звернення: 21.09.2020).

Дата надходження до редакиіiі: 24.09.2020 p.

Тетяна ЯкИМОвИЧ,

кандидат педагогічних наук,

стариий науковий співробітник,

доцент кафедри теорії і методики

технологічної освіти

Національного педагогічного університету

імені М. П. Драгоманова, м. Київ

Ірина ЗІНЧУК,

викладач кафедри іноземних мов

Національного університету «Львівська політехніка»

\section{ІНТЕГРАТИВНИЙ ПІДХІД ДО ФОРМУВАННЯ ПРОФЕСІЙНОГО МИСЛЕННЯ МАЙБУТНІХ ФАХІВЦІВ ТЕХНІЧНИХ СПЕЦІАЛЬНОСТЕЙ У ПРОЦЕСІ НАВЧАННЯ В ЗАКЛАДІ ВИЩОЇ ОСВІТИ}

У статті обтрунтовано інтегративний підхід, на основі якого розглянуто сутність та властивості професійного мислення із погляду різних наук (філософія, психологія, педагогіка). Виокремлено властивості професійного мислення майбутніх фахівиів технічних спеціальностей, щзо формуються у процесі навчання у закладі вищої освіти. Доведено, щзо формування професійного мисленнямайбутніх фахівців технічних спеціальностей у процесі навчання передбачає вирішення проблемних завдань, аналіз ситуацій, прийняття професійних рішень, вибір способів діяльності.

Ключові слова: інтегративний підхід, професійне мислення, професійна діяльність, професійна ситуачия, освітній проиес.

Обоснованно интегративный подход, на основе которого рассмотрена сущность и свойства профессионального мышления с позиций различных наук 